\title{
Chronic Myelocytic Leukemia
}

\section{ORIGIN OF SOME LYMPHOCYTES FROM LEUKEMIC STEM CELLS}

\author{
Philip J. Fialkow, Medical Genetics Section, Medical Service, Veterans \\ Administration Hospital, Seattle, Washington, 98108 and Departments of \\ Medicine and Genetics, University of Washington, Seattle, Washington 98195 \\ A. Michael Denman, Division of Immunological Medicine, Clinical Research Centre, \\ Watford Road, Harrow, Middlesex HA1 3UJ, England \\ Robert J. Jacobson and MARK N. Lowenthal, Baragwanath Hospital and \\ Department of Medicine, University of the Witwatersrand, \\ Johannesburg, South Africa
}

\begin{abstract}
A B S T RA C T In three patients with chronic myelocytic leukemia who were heterozygous at the X-linked glucose-6-phosphate dehydrogenase locus, lymphocytes were studied to determine if they had the same stem cell origin as the leukemic myeloid cells. Normal tissues such as skin had both B and A glucose-6-phosphate dehydrogenase isoenzymes, but the leukemic myelogenous cells displayed only one isoenzyme type, consistent with their clonal origin. A population of cells with undoubted thymus-derived (T)-lymphocyte characteristics had both isoenzymes. Presumably, then, these $T$ cells did not arise from the leukemic stem cell, either because they antedated the development of leukemia in that stem cell or, more likely, because they arose from progenitors not involved by the disease. In contrast, another population of lymphocytes showed only one isoenzyme type, suggesting that it arose from the chronic myelocytic leukemia stem cell. However, although this population contained many cells with the characteristics of bone marrow-derived (B) lymphocytes, it is not certain that the single enzyme produced by the cells over all can be attributed to B lymphocytes rather than to contaminating non-B-lymphoid cells.
\end{abstract}

\section{INTRODUCTION}

Isoenzyme (1-3) and chromosome marker studies (reviewed in reference 4) indicate that chronic myelo-

This work was presented in part at the 5th Cold Spring Harbor Conference on Cell Proliferation, 6-11 September 1977. A portion of this work appears in summary form in those proceedings.

Dr. Jacobson's present address is Division of Hematology, Department of Medicine, Georgetown University, Washington, D. C. 20007.

Received for publication 11 January 1978 and in revised form 12 May 1978. cytic leukemia $(\mathrm{CML})^{1}$ is a stem cell disorder which at the time of diagnosis, has unicellular origin. Thus far, it is known that the site of the abnormality is a pluripotent stem cell from which granulocytes, erythrocytes, platelets, and cultured blood monocytes/macrophages arise (2). That the CML stem cell may be pluripotent for lymphocytes as well as for myeloid elements is suggested by similarities between some cases in the acute phase (blast crisis) of CML and the common type of acute lymphoblastic leukemia (5-8) and by reports of the Philadelphia $\left(\mathrm{Ph}^{1}\right)$ chromosome in several patients with "acute lymphoblastic leukemia" without documented antecedent CML (e.g., 9-11). In contrast, when blood lymphocytes from CML patients are stimulated to divide in culture by phytohemagglutinin (PHA), they are reportedly $\mathrm{Ph}^{1}$-negative $(12,13)$. For this reason, some investigators believe that lymphocytes do not arise from the CML stem cell. However, these PHAresponsive cells are presumably long-lived; therefore, they may have antedated the development of the leukemic clone. Alternatively, they may reflect only one subpopulation, so that it is possible that other lymphocytes could be descendants of the CML stem cell. It is also conceivable that the development of CML requires several steps, one of which (e.g. formation of $\mathrm{Ph}^{1}$ ) occurs only in myelogenous cell precursors and not in lymphocytes.

To investigate the origin of different lymphocyte populations we studied three women with CML using as cell markers their chromosomes and the electro-

\footnotetext{
${ }^{1}$ Abbreviations used in this paper: CML, chronic myelocytic leukemia; E, erythrocyte; EAC, erythrocyte antibody complement; G-6-PD, glucose-6-phosphate dehydrogenase; $\mathrm{Ph}^{1}$, Philadelphia chromosome; PHA, phytohemagglutinin; PWM, pokeweed mitogen.
} 
phoretic pattern of glucose-6-phosphate dehydrogenase (G-6-PD), an X-linked isoenzyme. Because this locus undergoes $\mathrm{X}$-chromosome inactivation, only one G-6-PD gene is active in each somatic cell of adult females (14-16). Consequently, women heterozygous for the usual gene $\left(G d^{\mathrm{B}}\right)$ and a variant such as $G d^{\mathrm{A}}$, have two populations of cells - one synthesizing type $B$ enzyme, and the other, type A. Normal tissues contain a mixture of cells and manifest both $B$ and A enzymes (herein referred to as double-enzyme phenotypes). However, clonal proliferations display only single-enzyme phenotypes, B or A (see reference 4 for review). G-6-PD heterozygotes with CML have double-enzyme phenotypes in their normal tissues, but only one isoenzyme is found in blood granulocytes, erythrocytes, platelets, and cultured blood monocytes/ macrophages (2). Of the eight reported G-6-PD heterozygotes with CML, four have had type $A$ enzyme in their leukemia clones and four, type B (2). These observations strongly suggest clonal origin of CML and provide formal proof that it arises from hematopoietic pluripotent stem cells. The data reported here indicate that one population of thymus-derived (T) lymphocytes does not arise from this CML stem cell. However, the results also suggest that at least one other population of lymphoid cells does arise from the CML stem cells.

\section{SUBJECTS}

All three females in this report had typical $\mathrm{Ph}^{1}$-positive CML. They are subjects 6,7 , and 5 , respectively, in reference 2. M. K. was $60 \mathrm{yr}$ old when first seen in May 1975 . Her leukocyte count was $253,000 / \mathrm{mm}^{3}$ including $10 \%$ myeloblasts. V. M. was $28 \mathrm{yr}$ old on initial presentation in May 1975. She had a leukocyte count of $140,000 / \mathrm{mm}^{3}$ with $3 \%$ myeloblasts. F. M. was 35 yr old when first seen in December 1973. Her leukocyte count was $191,400 / \mathrm{mm}^{3}$ with $2 \%$ myeloblasts. On the patients' initial presentations, $\mathrm{Ph}^{1}$ was observed in 28 of 30 marrow metaphases from M. K. and in all of 30 metaphases from each of the other patients (2). After the diagnosis was established, the patients were treated with busulfan to control leukocytosis.

\section{METHODS}

\section{Collection and separation of leukocytes}

Samples of venous blood were anticoagulated with preservative-free heparin $(2 \mathrm{IU} / \mathrm{ml})$ and flown to London at ambient temperature. Processing of the specimens there was begun within $20 \mathrm{~h}$ of collection and all the preliminary manipulations were completed within the next $24 \mathrm{~h}$.

Initial preparative manipulations in all experiments were two cycles of density sedimentation on Ficoll/Hypaque gradients (Pharmacia Fine Chemicals, Div. of Pharmacia Inc., Piscataway, N. J.) (17). This procedure removed erythrocytes but not granulocyte precursors and immature forms even after several attempts to modify the method.

\section{T-lymphocyte preparation}

In most experiments, the sequential steps to isolate $\mathrm{T}$ cells were velocity sedimentation, rosette formation, and culture with PHA.

Velocity sedimentation. Nucleated leukocytes obtained by Ficoll/Hypaque sedimentation were first separated on the basis of differences in their size by velocity sedimentation at $1 \mathrm{~g}$ using a variation (18) of the method of Miller and Phillips (19). The volume distribution of the cells in each fraction was measured with a Coulter counter (Coulter Electronics Inc., Hialeah, Fla.). Differential counts were also performed on cytocentrifuge preparations of selected fractions to monitor their composition. Fractions were pooled which contained predominantly small lymphocytes sedimenting at 2.5-6.5 $\mathrm{mm} / \mathrm{h}$, or more rapidly sedimenting cells including occasional "blast" cells and numerous immature cells of the granulocyte series. The height of the "buffered step" gradient, duration of sedimentation, and volume of fraction collected $(25 \mathrm{ml})$ were kept constant so that small lymphocytes and other cell types were always removed in the same fraction.

Erythrocyte-rosette formation. Erythrocyte (E) rosettes were formed with neuraminidase-treated sheep erythrocytes (20). In a few experiments, $E$ rosettes were formed from cells remaining after erythrocyte antibody complement (EAC) rosetting (21). The $\mathrm{E}$ rosettes were separated on Ficoll/ Hypaque gradients (22).

Nylon fiber filtration. Nylon fiber filtration (23) was also used to improve the enrichment of $T$ cells in some experiments, but $2-5 \%$ of the lymphocytes that passed through the column were bone marrow-derived (B) cells.

Mitogen stimulation. To promote the preferential proliferation of lymphocytes, cells were cultured with PHA for 4-5 days before G-6-PD analysis.

\section{Non-T-lymphocyte preparation}

Two sets of experiments were performed. In most instances, the procedure was as outlined above for $T$ lymphocytes and the cells not removed by E-rosette formation were considered to be enriched with non-T lymphocytes. To promote preferential proliferation of lymphocytes, these cell populations were stimulated with pokeweed mitogen (PWM) for 4-5 days before G-6-PD analysis. In the second set of experiments, the leukocytes separated by Ficoll/Hypaque sedimentation were cultured with PWM for 7 days before lymphocyte isolation. Silica was added to the cultures on days 3 and 6 to destroy macrophages (24). Subsequent steps involved EAC-rosette formation and linear density gradients.

EAC-rosette formation. EAC rosettes were formed with erythrocytes sensitized with antibody and complement (21) and were isolated on Ficoll/Hypaque gradients (22).

Linear density gradient. In some experiments, slowly sedimenting, lymphoblast-enriched fractions were obtained before and after EAC-rosette formation by centrifuging the cultured cells in linear sucrose-serum density gradients (25). This technique was not effective in isolating unstimulated lymphocytes before culture.

\section{Cell characterization}

Morphology. Slide-centrifuge preparations were made from each fraction with a Shandon cytocentrifuge (Shandon Southern Instruments Inc., Sewickley, Pa.). The cells were stained with May-Grünwald Giemsa and classified morphologically as myeloblasts, erythrocyte or granulocyte precursors, mature granulocytes, monocytes, small lymphocytes, and lymphocytes transformed by exposure to PHA or PWM. 
These mitogen-transformed lymphoblasts were identified by the clumped nuclear chromatin, indistinct nucleoli, and darkblue agranular cytoplasm. At least 500 cells were scored in making the differential counts.

Lymphocyte characterization. E-rosette formation was used as the T-cell marker. In some experiments reaction with an anti-T-cell antiserum (26) was also employed. B-lymphocyte markers were cell-surface Ig receptors (27), intracellular Ig (28), and Ig synthesis. The ability of T and B lymphocytes from patients with CML to participate in Ig production stimulated by PWM was assayed by measuring the "helper" function of T cells and the synthesis of Ig by B cells. The CML $T$ and $B$ lymphocytes were prepared by the techniques appropriate for each blood sample. Each population was assayed separately in combination with normal lymphocyte populations $(29,30)$. Normal $T$ and B lymphocytes were tonsil Erosetting and non-E-rosetting cells, respectively. In most experiments, normal and CML lymphocytes were cultured at the optimal ratio for Ig synthesis of $75 \%$ B lymphocytes and $25 \% \mathrm{~T}$ lymphocytes in microtiter plates, $0.25 \times 10^{6}$ cells/ culture or in modified Marbrook chambers, $20.0 \times 10^{6}$ cells/ culture. The cells were stimulated with PWM and the supernate was harvested for Ig measurement after 7 days.

Lymphocyte response to phytomitogens was determined by culturing cells in microtiter plates with PHA, concanavalin A, or PWM (31).

Monocyte characterization. Monocytes were identified by phagocytosis of latex particles and fluorescence microscopy after staining with acridine orange or by the esterase method (32).

G-6-PD analysis. Cell lysates made by freezing and thawing were subjected to starch gel electrophoresis and the relative activity of the isoenzyme bands was estimated visually $(1,2)$. The sensitivity of this technique allows $5 \%$ activity of a minor isoenzyme component to be detected (33).

Cytogenetic analysis. Mitoses were examined after culturing the cells in the presence of PHA or PWM for 96-120 h from patients V. M. and M. K., and, for $48 \mathrm{~h}$ from F. M. The preparations were exposed to $0.05 \mu \mathrm{g} / \mathrm{ml}$ colchicine for $1 \mathrm{~h}$ before fixation and staining. Randomly selected, well-spread metaphases in which all G-group chromosomes were identified were scored for $\mathrm{Ph}^{1}$.

\section{RESULTS}

The major technical problem in these experiments involved isolating populations of cells which were acceptably homogeneous and recognizable unequivocally as small lymphocytes initially or as "lymphoblasts" after exposure to mitogens. Operationally, we defined a homogeneous population as one that contained at least $85 \%$ of cells fulfilling the morphologic criteria conventionally accepted for small lymphocytes or mitogen-stimulated lymphoblasts. In early experiments, the lymphocyte-enriched fractions were routinely tested for monocyte admixture and always had $<1 \%$ monocytes.

Freshly separated lymphocytes were identified as small round cells sedimenting at a velocity of between 3.5 and $4.7 \mathrm{~mm} / \mathrm{h}$ which were transformed by mitogens in culture. For example, in one representative experiment (Table I, exp. F. M. 1), the transformation ratios measured by tritiated thymidine incorporation of stimulated small cells to unstimulated small cells were 21.9 ,
16.9, and 10.1 for PHA, concanavilin A, and PWM, respectively.

Not all the methods for characterizing the isolated populations could be carried out in every experiment since the numbers of lymphocytes isolated were very limited. Thus, $200 \mathrm{ml}$ of blood, the largest blood sample we obtained, even from a normal person only contained $20 \times 10^{6} \mathrm{~B}$ lymphocytes. Furthermore, unusually large proportions of lymphocytes appeared as "null" cells (i.e. cells with neither T- nor B-lymphocyte surface markers); this we have attributed, at least in part, to the deleterious effect of repeated separation maneuvers. Similar manipulations on human spleen, lymph node, and tonsil cells led to a comparable increase in the proportion of cells lacking T- and B-cell markers. ${ }^{2}$

\section{G-6-PD in non-lymphoid cells}

On electrophoresis, extracts of skin and cultured skin fibroblasts from each patient manifested both $B$ and A G-6-PD isoenzymes (i.e., the patients were heterozygous for G-6-PD). Patients M. K. and F. M. had 50\% A and $50 \% \mathrm{~B} ; \mathrm{V}$. M. had about one-third $A$ and two-thirds B. In contrast, as on previous occasions (2), cells of the granulocyte series, erythrocytes, and platelets consistently displayed only one isoenzyme, type B.

\section{G-6-PD in lymphoid cells}

For simplicity, most of the preparative data have been omitted from the tables. Final lymphocyte preparations were included in the tabulated results only if they contained sufficient cells for satisfactory G-6-PD typing (at least $0.5 \times 10^{6}-1 \times 10^{6}$ viable lymphocytes) and if they were judged to contain at least $85 \%$ lymphocytes. In fact, the great majority of fractions included had over $95 \%$ lymphoid cells.

For tabulation, the fractions were grouped according to whether they had T- or non-T-cell characteristics and whether they showed both or only one G-6-PD type.

T-cells displaying both isoenzymes. In multiple experiments involving all three patients, a lymphocyte population was isolated which expressed both types of G-6-PD isoenzymes and therefore did not arise from the CML stem cell (Table I). When tested for surface markers, these cells manifested T-cell characteristics. They were most readily demonstrable when the patients were in complete clinical remission. The two exceptions are that at the times of exps. M. K. 4 and F. M. 1, the patients were in partial clinical remission. Only 3 of 585 PHA-stimulated cells in metaphase from the three patients were $\mathrm{Ph}^{1}$-positive.

Cells with T-lymphocyte characteristics displaying

${ }^{2}$ Denman, A. M., and B. K. Pelton. Unpublished observations. 
TABLE I

Isolation and Characterization of T-Lymphocytes Displaying Both G-6-PD

Isoenzymes from Patients V. M., M. K., and F. M. with CML*

\begin{tabular}{|c|c|c|c|c|c|c|}
\hline \multirow[b]{2}{*}{$\begin{array}{c}\text { Exp. } \\
\text { no. }\end{array}$} & \multirow[b]{2}{*}{ Date } & \multirow[b]{2}{*}{ Separation procedures $₫$} & \multirow[b]{2}{*}{ Mitogen§ } & \multicolumn{2}{|c|}{$\begin{array}{l}\text { Lymphocyte } \\
\text { markers" }\end{array}$} & \multirow[b]{2}{*}{$\begin{array}{c}\text { G-6-PDI\$ } \\
\text { (A:B) }\end{array}$} \\
\hline & & & & $\begin{array}{c}\mathbf{E} \\
\text { rosette }\end{array}$ & $\begin{array}{l}\text { Surface } \\
\text { Ig }\end{array}$ & \\
\hline & & & & \multicolumn{2}{|c|}{$\%$ of cells } & $\%$ \\
\hline V. M. 1 & $9 / 4 / 75$ & Veloc. sed. & PHA . & 20 & $<1$ & 20:80 \\
\hline \multirow[t]{2}{*}{5} & $8 / 17 / 76$ & Veloc. sed.; E rosetting & None & 100 & 6 & $10: 90$ \\
\hline & & Veloc. sed.; E rosetting & PHA & 27 & $<1$ & $35: 65$ \\
\hline \multirow[t]{2}{*}{6} & $6 / 7 / 77$ & None & PHA & ND & ND & $35: 65$ \\
\hline & & Veloc. sed. & PHA & ND & ND & $35: 65$ \\
\hline \multirow[t]{2}{*}{7} & $7 / 5 / 77$ & Veloc. sed.; E rosetting** & PHA & ND & ND & 45:55 \\
\hline & & Veloc. sed. & PHA & 77 & ND & $40: 60$ \\
\hline \multirow[t]{2}{*}{8} & $8 / 16 / 77$ & Veloc. sed. & None & 100 & 0 & 45:55 \\
\hline & & & PHA & 72 & 4 & $45: 55$ \\
\hline M. K. 1 & $9 / 4 / 75$ & Veloc. sed. & None & ND & ND & $10: 90$ \\
\hline \multirow[t]{5}{*}{2} & $8 / 18 / 76$ & E rosetting & PHA & 87 & 7 & $35: 65$ \\
\hline & & Nylon fiber filtration & PHA & 92 & 13 & $35: 65$ \\
\hline & & Veloc. sed. & PHA & 92 & $\mathbf{0}$ & $30: 70$ \\
\hline & & Veloc. sed. & PWM & 36 & 0 & $10: 90$ \\
\hline & & Veloc. sed.; E rosetting & PHA & 74 & $\mathbf{0}$ & $35: 65$ \\
\hline 4 & $4 / 6 / 77$ & Veloc. sed.; E rosetting & PHA & ND & ND & $40: 60$ \\
\hline F. M. 1 & $8 / 8 / 74$ & Veloc. sed. & None & ND & ND & $10: 90$ \\
\hline
\end{tabular}

* The CML clone in each patient displayed only type B G-6-PD.

† Only those cell populations that had enough cells to type for G-6-PD and at least 85\% cells (95\% in most fractions) judged morphologically to be lymphoid are included. The other cells were predominantly mature granulocytes. All other populations that contained enough cells to test displayed only type B G-6-PD.

§ Unstimulated cells were studied for G-6-PD immediately after separation and cells exposed to mitogen were studied after 4-5 days in culture.

"Anti-T-cell serum was used only in exp. M. K. 1. $25 \%$ of the cells reacted with the serum.

I Ig, immunoglobulin-positive; ND, not done; veloc. sed., velocity sedimentation.

** In this fraction, $\mathrm{E}$ rosettes were formed from cells remaining after EAC rosetting.

only one isoenzyme. The data are given in Table II. Since these cells were isolated by $\mathrm{E}$ rosetting and lacked surface or intracytoplasmic Ig, their characteristics were more consistent with $\mathrm{T}$-, rather than $\mathrm{B}$ lymphocyte origin. These cells appeared only when the disease was under poor control. In the two experiments in which chromosome analyses were done, 4 out of 76 metaphases were $\mathrm{Ph}^{1}$-positive (exps. V. M. 3 and 4).

Non-T cells. The fractions given in the upper panel of Table III were enriched for lymphocytes before mitogen stimulation. These fractions were prepared from the non-E-rosetting cells and contained appreciable numbers of cells with surface Ig. Only type B enzyme was detected in these cells, indicating their origin from the CML stem cell clone.

The supposition that the single enzyme type found in these non-T-cell fractions reflects the lymphoid cells is strengthened by exclusion of admixture with other cells. Important admixture with such cells as monocytes, granulocytes, and small myeloblasts was rendered unlikely by the high transformation ratios of mitogen-stimulated cells to unstimulated cells in the small cell fractions from which the non-T lymphocytes were prepared. Moreover, admixture with monocytes in such experiments as V. M. 2, 5, 7, and 8 was excluded by histochemical studies of the non-T-cell fractions before exposure to PWM and by morphological observations after mitogen stimulation. The latter procedure also revealed absence of granulocytes. Small myeloblasts could be confused with PWM-transformed lymphocytes, but they were not detected in the preparations before the mitogen was added and were not found in the patient's blood (she was in complete clinical remission at the time of exps. 7 and 8 ). Furthermore, cell survival studies (trypan blue exclusion) suggest strongly that after $4-5$ days in culture with 
TABLE II

Isolation and Characterization of Cells with T-Lymphocyte Attributes Displaying

Only Type B G-6-PD from Patients V. M. and M. K. with CML*

\begin{tabular}{|c|c|c|c|c|c|c|c|}
\hline \multirow[b]{2}{*}{$\begin{array}{c}\text { Exp. } \\
\text { no. }\end{array}$} & \multirow[b]{2}{*}{ Date } & \multirow[b]{2}{*}{$\begin{array}{l}\text { Separation } \\
\text { proceduret }\end{array}$} & \multirow[b]{2}{*}{ Mitogen $\S$} & \multicolumn{3}{|c|}{ Lymphocyte markers } & \multirow[b]{2}{*}{ G-6-PDIS } \\
\hline & & & & $\begin{array}{c}\mathrm{E} \\
\text { rosette }\end{array}$ & $\begin{array}{l}\text { Anti-T-cell } \\
\text { serum }\end{array}$ & $\begin{array}{c}\text { Surface } \\
\text { Ig }\end{array}$ & \\
\hline & & & \multicolumn{5}{|c|}{$\%$ of cells } \\
\hline V. M. 3 & $1 / 7 / 76$ & E rosetting & PHA & 22 & 60 & $<1$ & B \\
\hline V. M. 4 & $4 / 7 / 76$ & E rosetting" & PHA & 25 & ND & $\mathbf{0}$ & B \\
\hline M. K. 5 & $6 / 7 / 77$ & E rosetting" & PHA & ND & ND & $<1$ & B \\
\hline
\end{tabular}

Symbols *, $t, \S$ are explained in Table I.

"E rosetting was done on the small cells obtained by velocity sedimentation.

PWM, the blast cells are PWM-transformed lymphocytes rather than myeloblasts. Cell survival in PWMstimulated cultures regularly exceeded $50 \%$ when the cells were cultured initially from small cell pools enriched for lymphocytes and when at the time the cultures were terminated they contained at least $85 \%$ of cells resembling lymphoblasts or small lymphocytes. In contrast, cell survival was much poorer when pools of large, rapidly-sedimenting cells depleted of small lymphocytes were stimulated with PWM (data not shown in tables).
The lower panel of Table III shows the results of experiments in which the leukocytes obtained by Ficoll/Hypaque sedimentation were stimulated with PWM without any initial efforts to prepare small lymphocytes. B-lymphoblast enrichment was attempted after the stimulated cells had been cultured for 7 days. In keeping with the data presented in the upper panel of Table III, only type B enzyme was detected in these cells.

In experiments involving the culture of PWM-stimulated cells without any initial attempt to isolate small

TABLE III

Isolation and Characterization of Non-T Lymphocytes from Patients V. M. and M. K. with CML*

\begin{tabular}{|c|c|c|c|c|c|c|c|c|}
\hline \multirow{3}{*}{$\begin{array}{l}\text { Cells enriched for } \\
\text { lymphocytes before or } \\
\text { after culture with PWM }\end{array}$} & \multirow[b]{3}{*}{$\begin{array}{l}\text { Exp. } \\
\text { no. }\end{array}$} & \multirow[b]{3}{*}{ Date } & \multirow[b]{3}{*}{ Separation procedure $\downarrow \S$} & \multicolumn{4}{|c|}{ Lymphocyte markers } & \multirow[b]{3}{*}{ G-6-PD } \\
\hline & & & & \multicolumn{2}{|c|}{ Rosette } & \multicolumn{2}{|c|}{ Ig } & \\
\hline & & & & $\mathbf{E}$ & EAC & $\begin{array}{l}\text { Sur- } \\
\text { face }\end{array}$ & $\begin{array}{l}\text { Intra- } \\
\text { cytoplasmic }\end{array}$ & \\
\hline & & & & & & 6 of cell & & \\
\hline \multirow[t]{5}{*}{ Before $\ddagger$} & V. M. 2 & $11 / 25 / 75$ & Non-E rosetting" & 0 & ND & 25 & ND & B \\
\hline & 5 & $8 / 17 / 76$ & EAC rosetting & ND & 100 & 6 & ND & B \\
\hline & 7 & $7 / 5 / 77$ & Non-E rosetting & 0 & ND & ND & 11 & B \\
\hline & 8 & $8 / 16 / 77$ & Non-E rosetting & 20 & ND & ND & 18 & B \\
\hline & M. K. 5 & $6 / 5 / 77$ & Non-E rosetting & ND & ND & ND & 10 & B \\
\hline \multirow[t]{4}{*}{ After $¥$} & M. K. 6 & $1 / 3 / 78$ & EAC rosetting & 0 & 100 & ND & 29 & B \\
\hline & 7 & $2 / 1 / 78$ & EAC rosetting & 0 & 100 & ND & ND & B \\
\hline & 9 & $3 / 16 / 78$ & $\begin{array}{l}\text { Sucrose gradient before and } \\
\text { after EAC rosetting }\end{array}$ & 0 & 100 & ND & 46 & B \\
\hline & 10 & $4 / 12 / 78$ & $\begin{array}{l}\text { Sucrose gradient before and } \\
\text { after EAC rosetting }\end{array}$ & 0 & 100 & ND & 38 & B \\
\hline
\end{tabular}

See Table I for explanation of footnote symbols * and $\ddagger$.

\$ Fractions listed in the upper panel were isolated by velocity sedimentation before rosetting and culturing with PWM for 4-5 days. Fractions listed in the lower panel were stimulated with PWM for 7 days before lymphocyte enrichment procedures were done. In all of the latter group of experiments, silica was added to the cultured cells on days 3 and 6 .

"This fraction initially contained lymphocytes and granulocytes in a 1:1 ratio. The granulocytes were removed by allowing them to ingest carbonyl iron and removing them with a magnet yielding a residual population consisting of essentially $100 \%$ small lymphocytes. 
lymphocytes from other cells, admixture with monocytes was an additional problem. Contamination by these cells was reduced by exposing the cultures to silica during the course of PWM stimulation, a maneuver which does not interfere with the maturation of $B$ lymphocytes stimulated by this mitogen (24).

The non-T-cell lymphoid populations displaying only one G-6-PD isoenzyme were demonstrated both in remission (Table III, exps. V. M. 5, 7, and 8) and when the CML was under poor control (exps. V. M. 2, and M. K. 9 and 10). In the one chromosome analysis done, $\mathrm{Ph}^{1}$ was found in one of $37 \mathrm{PWM}$-stimulated metaphases (exp. V. M. 5).

Ig synthesis. In experiments designed to demonstrate that cells judged to be lymphocytes by other criteria indeed had immunological functions, Ig secretion was measured in T- and B-lymphocyte preparations from normal persons and from patients with CML. The results of one such experiment are given in Table IV. Both the T and B cells alone made some Ig, presumably because neither fraction was entirely homogeneous. Nonetheless, it is clear from this and similar experiments that synthesis of Ig by normal B cells was increased by $\mathrm{T}$ lymphocytes but not by other cells from patients with CML. Similarly, cells with B-cell characteristics from patients with CML made more Ig in the presence of normal $\mathrm{T}$ cells.

\section{DISCUSSION}

The three patients whose lymphocytes form the subject of this study are among the previously reported patients

TABLE IV

Ig Synthesis by Lymphocyte Subpopulations from a Normal Person and From Patient M. K. with CML

\begin{tabular}{llc}
\hline \multicolumn{2}{c}{ Source of cells* $^{*}$} & \\
\cline { 2 - 3 } T cells & B cells & Igt \\
\hline & & $\mu g / m l$ \\
CML & None & 0.6 \\
None & CML & 1.2 \\
Normal & None & 1.8 \\
None & Normal & 2.2 \\
Normal & Normal & 4.8 \\
CML & CML & 1.5 \\
CML & Normal & 3.8 \\
Normal & CML & 5.8 \\
(CML non-T) & Normal & 1.2 \\
\hline
\end{tabular}

* See Methods for preparation of normal and CML T and B lymphocytes. CML non- $T$ cells were the large cells after velocity sedimentation. The CML T-cell and the CML B-cell preparation had $100 \%$ lymphocytes. The CML non-T-cell preparation had $12 \%$ lymphocytes and $88 \%$ myelocytic cells. $\$$ Ig synthesis in microcultures of $B$ and $T$ lymphocytes stimulated with PWM for 7 days. Results are means of triplicate cultures. and their CML myelocytic cells are type $B$. The results provide evidence for the presence of two, and perhaps three lymphocyte populations in CML.

T lymphocytes which do not arise from CML stem cells. The most convincing conclusion reached from the data is that in each of the three patients there is a lymphocyte population which types as B/A for G-6-PD and therefore does not arise from the CML clone (Table I). These cells were most easily demonstrated when the patient was in complete clinical remission. This nonclonal lymphocyte population has many T-cell characteristics, such as spontaneous formation of rosettes with sheep erythrocytes and absence of readily detectable cell surface or intracytoplasmic Ig. Furthermore, these cells function as $\mathrm{T}$ lymphocytes in the synthesis of Ig. Cells within this population that enter mitosis in the presence of PHA lack $\mathrm{Ph}^{1}$.

One possible reason that these $\mathrm{T}$ lymphocytes are nonclonal is that they are long-lived and antedated the development of CML. Alternatively, nonclonal T lymphocytes may have been produced after leukemia is manifest. An argument in favor of the latter possibility is provided by experiments V.M. 6,7 , and 8 in Table I which were performed more than $2 \mathrm{yr}$ after the onset of CML. It is likely that a significant proportion of $T$ cells arose during this period and if all such cells originated from the CML clone, the greatest proportion of G-6-PD should have been of type B (the same type found in the CML clone). In contrast, the proportion of B:A in the T lymphocytes was the same as it was in skin.

Lymphocytes which arise from CML stem cells. The data also suggest that there are lymphocytes with the same single-enzyme phenotype as that found in the leukemia myeloid cells. Using lack of $\mathrm{E}$ rosetting as a criterion, one population of these lymphocytes consists predominantly of non-T cells. This population was demonstrated when the patient was in relapse or in clinical remission (Table III, exps. V. M. 2 and 7, respectively). Many of the cells in this population manifest B-lymphocyte characteristics such as cell surface and intracellular Ig, and Ig synthesis (Tables III and IV). However, since not all cells in the non-T-lymphocyte fractions showed, nor would be expected to show, these characteristics, it was possible that the preparations had important admixture with myeloid cells which had a single-enzyme phenotype and obscured the phenotype in the lymphocytes themselves. For the reason given in the Results we feel that we have excluded contamination with the most obvious nonlymphoid cell types. Although some T-"lymphoblast" admixture is to be expected, if it were considerable it would, if anything, have favored the appearance of a double-enzyme phenotype (cf. G-6-PD in preparations from Tables I and III, exps. V. M. 5, 7, and 8).

These results suggest strongly that there are lympho- 
cytes which arise from the CML stem cell. Although the percentages of these lymphocytes that have B-cell characteristics resemble the percentages found in similar preparations of PWM-transformed B cells from normal subjects $(28),{ }^{2}$ we do not know the extent to which the cells without T- or B-cell markers represent B lymphocytes which have lost their markers as a consequence of the prolonged separation procedures or represent physiologically "null" lymphoid cells. We recognize that ultimate proof for the CML-stem cell origin of B lymphocytes requires G-6-PD assays of pools in which the great majority of cells can be definitively identified as B lymphocytes or of B-cell colonies grown in culture. However, there are few criteria by which B lymphocytes and precursor cells of the myeloid series can be firmly distinguished in CML. Ia antigens are not confined to $B$ lymphocytes but are expressed by both normal myeloid stem cells $(34,35)$ and neoplastic granulocytes in CML (36). Moreover, there is evidence that in blast crisis leukemic cells may display both lymphoid and myeloid properties (37). Indeed in blastic CML, cells with myeloblastic morphology may express terminal transferase (38), an enzyme usually considered to be characteristic of primitive lymphoid cells. On the basis of the semiquantitative data presented here we suggest tentatively that the single-enzyme phenotypes in the non-T-lymphocyte fractions may represent $B$ cells and, therefore, that B lymphocytes may arise from CML stem cells.

$T$ lymphocytes which may arise from CML stem cells. There is a population of lymphocytes which has a single-enzyme phenotype and $\mathrm{T}$-cell characteristics including lack of cell-surface Ig, formation of $E$ rosettes, and reaction with anti-T-cell serum (Table II). In contrast to the non-clonal $\mathrm{T}$ cells which were most easily demonstrated in clinical remission, this "clonal" subpopulation has thus far been demonstrated only when the disease is in relapse. However, conclusions based on these findings must be guarded. Thus, since the disease was active at the times of study, the still greater preponderance of cells of the granulocyte series in the starting material increased the difficulties of isolating and characterizing lymphocyte populations. Furthermore, it cannot be firmly concluded that this clonal subpopulation is analogous to normal T lymphocytes since it may consist of B lymphocytes or undifferentiated cells of the leukemic clone which have acquired Tcell markers during the evolution of the leukemia.

Previously it has been concluded that the lymphoid and myeloid systems share a common multipotent stem cell in mice (39-41) and that in these animals there are also restricted stem cells committed to differentiate only into T lymphocytes or only into myeloid cells (41). Independent differentiation into B lymphocytes was not observed. The data for man are less clear, but our observations suggest that there are similar stem cells in humans and that CML involves a pluripotent stem cell. The occurrence of lymphocytes which arise from the CML stem cell may explain why in some cases of blast crisis, the cells have morphologic, enzymatic, immunologic, and other characteristics which resemble those found in the common type of acute lymphoblastic leukemia (5-8). The demonstration in patients with $\mathrm{CML}$ in remission of $\mathrm{T}$ lymphocytes that do not arise from the leukemia stem cell may reflect persistence of restricted stem cells committed to differentiate only into $\mathrm{T}$ cells.

Philadelphia chromosome (Ph $\left.{ }^{1}\right)$. PHA- and PWMstimulated mitoses within the lymphocytes having single-enzyme phenotypes (and thereby presumably arising from CML stem cells) generally lacked $\mathrm{Ph}^{1}$. It is possible that the cells in metaphase are not representative of the vast majority of enzyme-producing cells or that cells which are clonally derived only acquire $\mathrm{Ph}^{1}$ at a later stage in leukemogenesis or perhaps even after it has occurred. Our data do not allow us to distinguish between those and other possibilities, but this question can be resolved by analysis of both G-6-PD and $\mathrm{Ph}^{1}$ in the progeny of single cells derived from hematopoietic cell colonies grown in culture.

In summary, the likely demonstration in CML of clonal lymphocytes, be they B cells, null cells, or both, suggests that there is a common hematopoietic stem cell for some lymphocytes as well as for myelogenous cells and it is this stem cell which is involved in the leukemia. Some cells with T-lymphocyte characteristics may also arise from the pluripotent progenitor, but one population of $T$ cells does not arise from the CML stem cell either because it antedates the development of leukemia in that stem cell or, more likely, because it arises from progenitors not involved by the disease.

\section{ACKNOWLEDGMENTS}

We thank Dr. George Janossy for advice in the design of separation procedures, Dr. Grace Penfold and Dr. Ivan A. F. Dukes for hematological studies, and Peta Basford, Jean Buiter, Camille Campbell, Michelle Henfrey, Gabe Herner, Trevor Perkins, Armi Salo, and Laura Steinmann for their skillful assistance.

This research was supported by grants CA 16448 and GM 15253 from the National Cancer Institute and Institute of General Medical Sciences, National Institutes of Health, Department of Health, Education and Welfare; the Medical Research Service of the Veterans Administration; and by NATO Research grant 742.

\section{REFERENCES}

1. Fialkow, P. J., S. M. Gartler, and A. Yoshida. 1967. Clonal origin of chronic myelocytic leukemia in man. Proc. Natl. Acad. Sci. U. S. A. 58: 1468-1471.

2. Fialkow, P. J., R. J. Jacobson, and T. Papayannopoulou. 1977. Chronic myelocytic leukemia: clonal origin in a 
stem cell common to the granulocyte, erythrocyte, platelet and monocyte/macrophage. Am. J. Med. 63: 125-130.

3. Fialkow, P. J., R. Lisker, J. Detter, E. R. Giblett, and C. Zavala. 1969. 6-Phosphogluconate dehydrogenase: hemizygous manifestation in a patient with leukemia. Science (Wash. D. C.). 163: 194-195.

4. Fialkow, P. J. 1976. Clonal origin of human tumors. Biochim. Biophys. Acta. 458: 283-321.

5. Boggs, D. R. 1974. Hematopoietic stem cell theory in relation to possible lymphoblastic conversion of chronic myeloid leukemia. Blood. 44: 449-453.

6. McCaffrey, R., T. A. Harrison, R. Parkman, and D. Baltimore. 1975. Terminal deoxynucleotidyl transferase activity in human leukemic cells and in normal human thymocytes. N. Engl. J. Med. 292: 775-780.

7. Sarin, P. S., P. N. Anderson, and R. C. Gallo. 1976. Terminal deoxynucleotidyl transferase activities in human blood leukocytes and lymphoblast cell lines. High levels in lymphoblast cell lines and in blast cells of some patients with chronic myelogenous leukemia in acute phase. Blood. 47: 11-20.

8. Janossy, G., M. Roberts, and M. F. Greaves. 1976. Target cell in chronic myeloid leukaemia and its relationship to acute lymphoid leukaemia. Lancet. II: 1058-1061.

9. Propp, S., and F. A. Lizzi. 1970. Philadelphia chromosome in acute lymphocytic leukemia. Blood. 36: 353-360.

10. Schmidt, R., H. Dar, M. Santorineou, and I. Sekine. 1975. $\mathrm{Ph}^{1}$ chromosome and loss and reappearance of the $\mathrm{Y}$ chromosome in acute lymphocytic leukaemia. Lancet. I: 1145.

11. Peterson, L. C., C. D. Bloomfield, and R. D. Brunning. 1976. Blast crisis as an initial or terminal manifestation of chronic myeloid leukemia. A study of 28 patients. Am. J. Med. 60: 209-220.

12. Tough, I. M., P. A. Jacobs, W. M. Court Brown, A. G. Baikie, and E. R. D. Williamson. 1963. Cytogenetic studies on bone-marrow in chronic myeloid leukaemia. Lancet. I: 844-846.

13. Whang, J., E. Frei, III, J. H. Tjio, P. P. Carbone, and G. Brecher. 1963. The distribution of the Philadelphia chromosome in patients with chronic myelogenous leukemia. Blood. 22: 664-673.

14. Beutler, E., M. Yeh, and V. F. Fairbanks. 1962. The normal human female as a mosaic of X-chromosome activity: studies using the gene for G-6-PD deficiency as a marker. Proc. Natl. Acad. Sci. U. S. A. 48: 9-16.

15. Davidson, R. G., H. M. Nitowsky, and B. Childs. 1963. Demonstration of two populations of cells in the human female heterozygous for glucose-6-phosphate dehydrogenase variants. Proc. Natl. Acad. Sci. U. S. A. 50: 481-485.

16. DeMars, R., and W. E. Nance. 1964. Electrophoretic variants of glucose-6-phosphate dehydrogenase and the single-active- $X$ in cultivated human cells. In Retention of Functional Differentiation in Cultured Cells. V. Efendi, editor. The Wistar Institute Press, Philadelphia. 35-48.

17. Boyum, A. 1968. Separation of leucocytes from blood and bone marrow. Scand. J. Clin. Lab. Invest. 21(Suppl. 97): 77-89.

18. Denman, A. M., and B. K. Pelton. 1973. Cell separation by size. In Methodological Developments in Biochemistry. E. Reid, editor. Longman, Inc., 2: 185.

19. Miller, R. G., and R. A. Phillips. 1969. Separation of cells by velocity sedimentation. J. Cell. Physiol. 73: 191-201.

20. Bentwich, Z., S. D. Douglas, E. Skutelsky, and H. G.
Kunkel. 1973. Sheep red cell binding to human lymphocytes treated with neuraminidase; enhancement of $\mathrm{T}$ cell binding and identification of a subpopulation of $B$ cells. J. Exp. Med. 137: 1532-1537.

21. Stjernsward, J., M. Jondal, F. Vanky, H. Wigzell, and R. Sealy. 1972. Lymphopenia and change in distribution of human B and T lymphocytes in peripheral blood induced by irradiation for mammary carcinoma. Lancet. I: $1352-1356$.

22. Wybran, J., S. Chantler, and H. H. Fudenberg. 1973. Isolation of normal T-cells in chronic lymphatic leukemia. Lancet. I: $126-129$.

23. Julius, M. H., E. Simpson, and L. A. Herzenberg. 1973. A rapid method for the isolation of functional, thymusderived cells. Eur. J. Immunol. 3: 645-649.

24. O'Rourke, E. J., S. B. Halstead, A. C. Allison, and T. A. E. PlattsMills. 1978. Specific lethality of silica for human peripheral blood mononuclear phagocytes in vitro. $J$. Immunol. Methods. 19: 137-151.

25. Yoshida, Y., and D. G. Osmond. 1971. Blastogenic response of lymphocytes separated from bone-marrow to allogeneic lymphoid cells in vitro. Immunology. 21: 767-779.

26. Denman, A. M., and B. K. Pelton. 1974. Control mechanisms in infectious mononucleosis. Clin. Exp. Immunol. 18: $13-25$.

27. Brown, G., and M. F. Greaves. 1974. Cell surface markers for human $\mathrm{T}$ and B lymphocytes. Eur. J. Immunol. 4: $302-310$.

28. Broom, B. C., E. G. de la Concha, A. D. B. Webster, G. J. Janossy, and G. L. Asherson. 1976. Intracellular immunoglobulin production in vitro by lymphocytes from patients with hypogammaglobulinaemia and their effect on normal lymphocytes. Clin. Exp. Immunol. 23: 73-77.

29. de la Concha, E. G., G. Oldham, A. D. B. Webster, G. L. Asherson, and T. A. E. PlattsMills. 1977. Quantitative measurements of $\mathrm{T}$ - and B-cell function in 'variable' primary hypogammaglobulinaemia: evidence for a consistent B-cell defect. Clin. Exp. Immunol. 27: 208-215.

30. Pelton, B. K., R. C. Imrie, and A. M. Denman. 1977. Susceptibility of human lymphocyte populations to infection by herpes simplex virus. Immunology. 32: 803-810.

31. Janossy, G., and M. F. Greaves. 1971. Lymphocyte activation. I. Response of T and B lymphocytes to phytomitogens. Clin. Exp. Immunol. 9: 483-498.

32. Tucker, S. B., R. V. Pierre, and R. E. Jordan. 1977. Rapid identification of monocytes in a mixed mononuclear cell preparation. J. Immunol. Methods. 14: 267-269.

33. Fialkow, P. J. 1973. Primordial cell pool and lineage relationships of five human cell types. Ann. Hum. Genet. 37: $39-48$.

34. Cline, M. J., and R. Billing. 1977. Antigens expressed by human B lymphocytes and myeloid stem cells. J. Exp. Med. 146: 1143-1145.

35. Ross, G. D., C. I. Jarowski, E. M. Rabellino, and R. J. Winchester. 1978. The sequential appearance of Ia-like antigens and two different complement receptors during the maturation of human neutrophils. J. Exp. Med. 147: 730-744

36. Billing, R. J., B. Rafizadeh, I. Drew, G. Hartman, R. Gale, and P. Terasaki. 1976. Human B-lymphocyte antigens expressed by lymphocytic and myelocytic leukemia cells. I. Detection by rabbit antisera. J. Exp. Med. 144: 167178.

37. Forman, E. N., T. Padre-Mendoza, P. S. Smith, B. E. 
Barker, and P. Farnes. 1977. $\mathrm{Ph}^{1}$-positive childhood leukemias: spectrum of lymphoid-myeloid expressions. Blood. 49: 549-558.

38. Marks, S. M., D. Baltimore, and R. McCaffrey. 1978. Terminal transferase and response to vincristineprednisone in blastic chronic myelogenous leukemia. $N$. Engl. J. Med. 298: 812-814.

39. Wu, A. M., J. E. Till, L. Siminovitch, and E. A. McCulloch. 1968. Cytological evidence for a relationship between normal and hematopoietic colony-forming cells and cells of the lymphoid system. J. Exp. Med. 127: 455-464.

40. Edwards, G. E., R. G. Miller, and R. A. Phillips. 1970. Differentiation of rosette-forming cells from myeloid stem cells. J. Immunol. 105: 719-729.

41. Abramson, S., R. G. Miller, and R. A. Phillips. 1977. The identification in adult bone marrow of pluripotent and restricted stem cells of the myeloid and lymphoid systems. J. Exp. Med. 145: 1567-1579. 